\title{
Behaviour of arsenic on the continental shelf off the Gironde estuary: role of phytoplankton in vertical fluxes during spring bloom conditions
}

\author{
Pierre MICHEL ${ }^{a_{*}}$, Bernard BOUTIER ${ }^{a}$, Alain HERBLAND ${ }^{b}$, Bernard AVERTY ${ }^{a}$, Luis Felipe ARTIGAS ${ }^{\mathbf{c}}$, \\ Dominique AUGER a ${ }^{\text {, Emanuelle CHARTIER }}{ }^{\text {a }}$ \\ a IFREMER, BP 1105, 44311 Nantes cedex; France \\ ${ }^{\mathrm{b}}$ CREMA, BP 5, 17137 L'Houmeau, France \\ ${ }^{\mathrm{c}}$ Université de Bordeaux I, 33405 Talence cedex, France
}

(Revised 29/08.97, accepted 25/09/97)

\begin{abstract}
The arsenic (As) cycle in the marine environment is known to be sensitive to biological activity. Within the scope of the National Coastal Oceanography Program, we undertook a specific study of the behaviour of this element in a water column on the continental shelf of the Bay of Biscay off the Gironde estuary during two oceanographic cruises conducted in May 1994 and May 1995. Various chemical forms were measured: arsenite (As3), arsenate (As5), monomethylarsenic (MMA), dimethylarsenic (DMA) and dissolved total As after ultraviolet mineralization. The net flux of total As from the Gironde estuary was cvaluated as well as its effect on the concentration in surface marine waters. The vertical profiles in the coastal zone during a period of active primary production confirmed a certain analogy between arsenates and phosphates as well as the formation of $\Lambda \mathrm{s} 3$ and DM $\Lambda$. The importance of organoarsenic species not directly accessible to the formation of volatile hydrides is demonstrated. Their presence modifies assessments, reducing the deficit of dissolved total As in the euphotic layer to just $5 \%$. For particles, the As content in phytoplankton was estimated at $6 \mu \mathrm{g} \cdot \mathrm{g}^{-1}$ compared to 20 to $30 \mu \mathrm{g} \cdot \mathrm{g}^{-1}$ in iron- and aluminium-rich terrigenous particles. These results do not invalidate the role of phytoplankton in the speciation of dissolved As but indicate that their involvement in vertical transfers was apparently not predominant in the zone under study. (C) Elsevier, Paris
\end{abstract}

\section{arsenic / phytoplankton / speciation / Gironde plume / Biscay Bay}

Résumé - Comportement de l'arsenic sur le plateau continental au large de l'estuaire de la Gironde : rôle du phytoplancton dans le flux vertical en situation de bloom printanier. Le cycle de l'arsenic en milieu marin est bien connu pour sa sensibilité à l'activité biologique. Dans le cadre du Programme National d'Océanographie Côtière, nous avons étudié de manière plus précise le comportement de cet élément dans la colonne d'eau sur le plateau continental du Golfe de Gascogne, au large de la Gironde. Deux campagnes océanographiques ont été réalisées en avril 1994 et mai 1995. Nous avons mesuré les diverses formes chimiques: arsénite (As3), arséniate (As5), monométhylarsenic (MMA), diméthylarsenic (DMA) ainsi que l'As total dissous après minéralisation UV. Le nux net d'As total issu de la Gironde a élé évalué ainsi que son influence sur la concentration dans les eaux marines superficielles. Les profils verticaux en zone côtière, pendant une période active de production primaire, confirment une certaine analogie entre arséniates et phosphates, ainsi que la formation d'As3 et de DMA. L'importance d'espèces organoarséniées inaccessibles directement à la formation d'hydrures volatils, est démontrée. Cette présence influe sur les bilans et réduit à $5 \%$ seulement le déficit en As total dissous dans

\footnotetext{
* Correspondence and reprints
} 
la couche euphotique. Concernant les particules, on évalue à $6 \mu \mathrm{g} \cdot \mathrm{g}^{-1}$ la teneur en $\Lambda \mathrm{s}$ du phytoplancton contre 20 à $30 \mu \mathrm{g} \cdot \mathrm{g}^{-1}$ dans les particules terrigènes riches en Fe et en Al. Sans remettre en cause l'importance du phytoplancton dans la spéciation de l'As dissous, son implication dans les transferts verticaux ne semble pas prédominante dans la zone d'étude. (C) Elsevier, Paris

\section{arsenic / phytoplancton / spéciation / panache de la Gironde / golfe de Gascogne}

\section{INTRODUCTION}

The biogeochemical behaviour of arsenic has often been studied in estuarine or oceanic environments. However, fewer studies have been conducted on the continental shelf, and Sanders [28], in his attempt to model the arsenic cycle, noted uncertainties due to a lack of data. The metabolization of arsenates by phytoplankton and their transformation into soluble reduced species such as arsenites (As3), monomethylarsenic (MMA) or dimethylarsenic (DMA) have been largely documented $[1,3,11$, 20, 26, 27]. Although metabolization modifies arsenic reactivity, it has not been demonstrated that in coastal areas phytoplankton play a major role in vertical transfers of this element. It should be noted that the measurements made by most authors concern only chemical species likely to form volatile arsines in the presence of sodium borohydride. Howard and Comber [12] showed the presence of more complex chemical forms inaccessible to this method. As a result, there is a chronic underestima tion of total arsenic and an overestimation of its deficit in the euphotic layer. Thus, the present study attempted to define the role of phytoplanktonic activity in vertical movements of arsenic in a coastal area. Performed in the context of the National Coastal Oceanography Program, it concerns the more general problem of the biogeochemical behaviour of certain trace elements (cadmium, chromium, arsenic) on the Atlantic continental shelf in relation to biological activity and water flow. The constitution of a multidisciplinary team capable of dealing with both biological and hydrodynamic aspects was an essential requirement for this undertaking.

\section{MATERIALS AND METHODS}

\subsection{Samples}

The study zone was locatcd on the continental shelf of the Bay of Biscay between the Gironde estuary and the slope of the shelf (figure 1 ). The results presented here were obtained during two oceanographic cruises conducted in
1994 and 1995 . The PNOCAT-2 cruise from 7 to 17 May 1994, aboard the R/V Thalia involved a transect from the mouth of the Gironde estuary where salinities range between 20 and $34 \times 10^{-3}$, a series of seven vertical profiles relative to a mass of drifting water centred on $45^{\circ} 45^{\prime} \mathrm{N}$ and $2^{\circ} \mathrm{W}$ in depths of $70 \mathrm{~m}$, and two reference profiles in depths of 100 and $200 \mathrm{~m}$. The BIOMET cruise from 3 to 25 May 1995, aboard the $R / V$ Poseidon involved the same elements, except that the general location for obtaining samples above the continental shelf was set more to the south $\left(45^{\circ} 00^{\prime} \mathrm{N}\right)$ to minimize the influence of Loire River waters (as indicated by the hydrodynamic model).

Samples were obtained using a Teflon pump and a $250 \mathrm{~m}$ polyethylene tube. A TSD probe attached to the sampling tube allowed simultaneous acquisition of hydrologic profiles. Samples were immediately passed through a $0.4 \mu \mathrm{m}$ polycarbonate Nuclepore filter. These operations were performed on board, under clean laboratory conditions. For As3 measurement in 1994, a $40 \mathrm{~mL}$ aliquot was immediately frozen in liquid nitrogen and stored until analysis. This form of storage, though used in various studies, is not entirely satisfactory [6]. Therefore, our As3 measurements in 1995 were performed immediately using an on-board analysis system. Sample storage was thus simplified, and the results were more reliable. For subsequent analyses of As5, MMA, DMA and total arsenic, the samples were acidified at $\mathrm{pH} 2.0$ by $\mathrm{H}_{2} \mathrm{SO}_{4}$ and stored in darkness for no longer than 1 month.

\subsection{Analyses}

The measurement system used, adapted from that of Michel et al. [17], was based on the generation of volatile hydrides, with trapping in liquid nitrogen at $-196{ }^{\circ} \mathrm{C}$ followed by gas chromatography. The system was automated, and atomic fluorescence detection replaced atomic absorption measurcment, thus allowing greater sensitivity with a smaller and easily embarkable unit. Measurement of arsenic by atomic fluorescence has already been performed by Ebdon et al. [7] with an expe- 


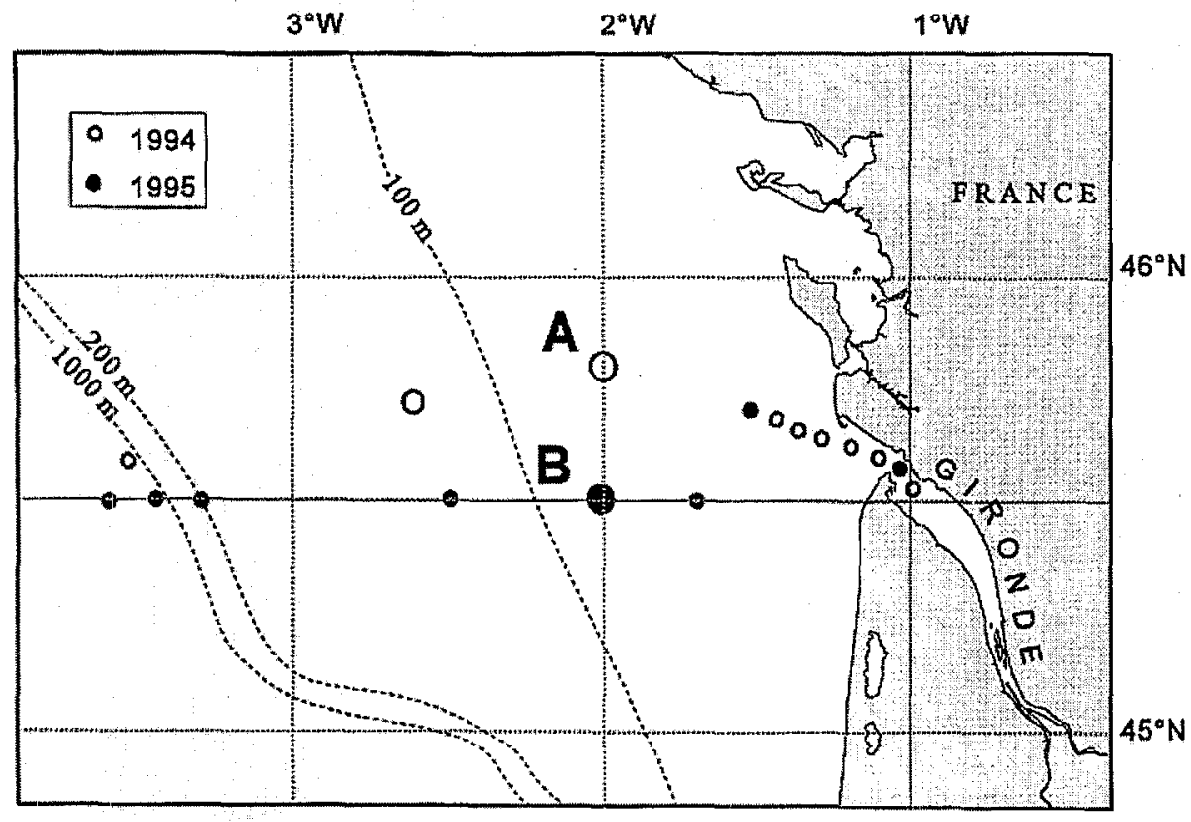

Figure 1. Location of the sampling stations.

Figure 1. Position des stations d'échantillonnage.

rimental system. We used a recently marketed PSAnalytical detector which was adapted for speciation purposes. The sensitivity of the system was $0.02 \mathrm{nmol} \cdot \mathrm{L}^{-1}$ for dissolved arsenic. Measurements of As3 + As5, MMA and DMA in water were performed at $\mathrm{pH}$ 1.0. For As3 it was necessary to repeat the measurement at $\mathrm{pH} 5.0$. The sum of the chemical species thus measured (AsS) was often lower than dissolved total arsenic.

To measure dissolved total arsenic (AsT), it is essential to mineralize the samples. Two procedures were tested for this purpose: a chemical process using $\mathrm{HClO} 4$ at $205^{\circ} \mathrm{C}$ after evaporation of the sample, and a photochemical process using a $1500 \mathrm{~W}$ high-pressure ultraviolet (UV) lamp for $16 \mathrm{~h}$. The results obtained with the two methods were appreciably the same, although UV mineralization did not requirc any reagents or modification of volumes. After mineralization, AsT was transformed totally into As5 and measured as indicated earlier. The absence of methylarsines during this determination was considered to be a proof of the total mineralization of organoarsenic species.

Particulate arsenic was determined as described earlier after wet mineralization at $205^{\circ} \mathrm{C}$ using a $\mathrm{HNO}_{3} / \mathrm{H}_{2} \mathrm{SO}_{4}$ ' $\mathrm{HClO}_{4}$ mixture $(4: 1: 1 \mathrm{v} / \mathrm{v})$.
Measurement of NASS -4 and PACS-1 certified samples ensured the quality of analyses of dissolved and particulate fractions.

Phosphate (more exactly reactive inorganic phosphorus) was determined immediately after sampling according to the method of Murphy and Riley [24] using a $10 \mathrm{~cm}$ path length cell. Chlorophyll was determined by passage through a GFF filter, extraction in $90 \%$ acetone and analysis by high-performance liquid chromatography. Primary production was measured by the ${ }^{14} \mathrm{C}$ method, with incubation in situ between the morning ( $8 \mathrm{a} . \mathrm{m}$.) and the cvening ( 8 p.m.). Radioactivity counts were performed on board using a liquid scintillator.

\section{RESULTS AND DISCUSSION}

\subsection{Gironde inputs}

The model of Boyle et al. [5] was used to estimate Gironde arsenic inputs; assuming that for a salinity interval of 20 to $34 \times 10^{-3}$, the hypothesis of conservativity of arsenic would seem reasonable for the two cruises we conducted off the Gironde estuary. The regression lines 


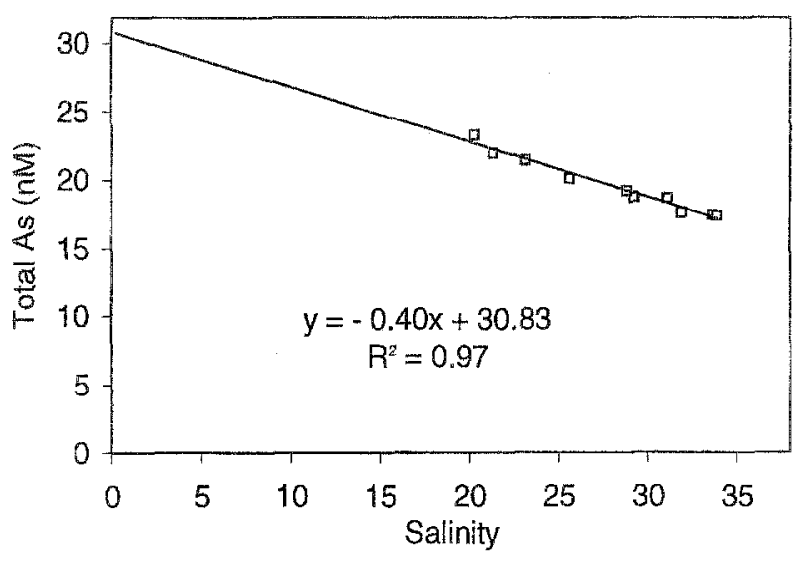

Figure 2. Dilution curve for total arsenic (AsT) in the Gironde estuary on 5 May 1994.

Figure 2. Droite de dilution de l'arsenic total (AsT) en Gironde le 5 mai 1994.

calculated in these two cases had the following characteristics: 5 May 1994, AsT $=-0.40 \mathrm{~S} 10^{-3}+30.83$ $\left(R^{2}=0.97\right) ; 10$ May 1995 , AsT $=-0.36 \mathrm{~S} 10^{-3}+31.73$ $\left(R^{2}=0.97\right)$. The dilution curve obtained in 1994 is represented by way of example in figure 2. The concentrations of total arsenic in Gironde freshwater were thus evaluated, respectively, as 30.8 and $29.1 \mathrm{nmol} \cdot \mathrm{L}^{-1}$ in 1994 and 1995. These levels were $40 \%$ lower than those measured in 1984 by Seyler and Martin [29] but an average $50 \%$ higher than our oceanic measurements during these cruises. In the estuary, biogenic forms (As3, MMA and DMA) were not well represented ( 1 to $3 \%$ ); their proportion was only notable for salinities above 30 . High turbidities limiting photosynthesis were the most likely cause of this condition.

Estimation of flux of dissolved arsenic should take into account both extrapolated concentrations with null salinities and water flows upstream from the dynamic tide. In view of water residence times within the estuary, we took into consideration the mean flow during the 30 days preceding sampling. For the radials performed on 5 May 1994 and 10 May 1995, freshwater flows were thus estimated as $439 \mathrm{~kg} . \mathrm{d}^{-1}$ in May 1994 and $166 \mathrm{~kg} . \mathrm{d}^{-1}$ in May 1995.

Estimation of flux of particulate arsenic requires knowledge of particle flow and arsenic load. For salinities of less than 30 , the suspended particulate material (SPM) load was high (9 to $23 \mathrm{mg} \cdot \mathrm{L}^{-1}$ in 1994 and 8 to $34 \mathrm{mg} \cdot \mathrm{L}^{-1}$ in 1995). These particles were rich in metallic hydroxides (iron $=3.7$ to $4.6 \%$; aluminium $=7.4$ to $10.5 \%)$ and correlatively in total arsenic (25 to $34 \mu \mathrm{g} \cdot \mathrm{g}^{-1}$ ). Estimation of the flow of particulate material toward the ocean varies according to the year and hydrologic conditions. According to Jouanneau [14], mean annual flow is $10^{6}$ metric tons. The result would be a mean flow of particulate arsenic toward the ocean of 25 to 34 metric tons/year (68 to $73 \mathrm{~kg} \cdot \mathrm{d}^{-1}$ ), with very great variability depending on water levels. This particulate arsenic flow is not negligible when compared to dissolved flows.

\subsection{Vertical distribution of dissolved arsenic and speciation}

A major objective of our study was to study the behaviour of arsenic in the water column in a period of high primary production. Accordingly, we tracked a mass of drifting water identified by a buoy with a floating anchor $40 \mathrm{~m}$ below the surface. This buoy also served as a support for a particle trap placed below the pycnocline as well as for a line to measure primary production. Tracking was performed at station A from 10 to 17 May 1994, and at station B from 18 to 25 May 1995. During these two periods, the daily vertical profile of total arsenic and its various chemical forms was studied and corresponding biological and hydrologic data obtained. The absence of any notable changes during these two periods facilitated statistical presentation of the data. Table I shows the hydrologic characteristics and mean measurements of dissolved arsenic in all its chemical forms. By way of example, figure 3 shows the data for May 1995.

The drift of the water masses was subjected essentially to dominant winds. According to Lazure and Jégou [16], the residence time of freshwater at station A in 1994 and at station B in 1995 was several months. Moreover, an input from the Loire River related to an atypical weather situation cannot be excluded. The proportion of freshwater in the surface layer was $2.2 \%$ in 1994 and $5.5 \%$ in 1995 . Surface water temperature ranged between 13 and $15^{\circ} \mathrm{C}$, a level rather favourable to bacterial or phytoplanktonic biological activity. The coinciding effects of salinity and temperature induced a pycnocline of between 35 and $40 \mathrm{~m}$ for both years.

Measurements of total arsenic performed below the pycnocline gave mean values of 19.7 and $20.2 \mathrm{nmol} \cdot \mathrm{L}^{-1}$ in 1994 and 1995, in agreement with the results of Statham et al. [30] (19.9 $\left.\mathrm{nmol} \cdot \mathrm{L}^{-1}\right)$, Middelburg et al. [19] (18.3 to $\left.20.3 \mathrm{nmol} \cdot \mathrm{L}^{-1}\right)$, Michel et al. [18] $\left(18.4 \pm 1.2 \mathrm{mmol} \cdot \mathrm{L}^{-1}\right)$ and Cutler and Cutter [6] (17.8 to 
Table I. Mean results (and standard deviations) expressed as nmol. $\mathrm{L}^{-1}$ as a function of depth (m) at station $\Lambda$ in May 1994 and at station B in May 1995.

Tableau I. Résultats moyens et (écarts-types) en phase dissoute, exprimés en nmol.L $\mathrm{L}^{-1}$, en fonction de la profondeur (m), à la station A en mai 1994 et à la station B en mai 1995.

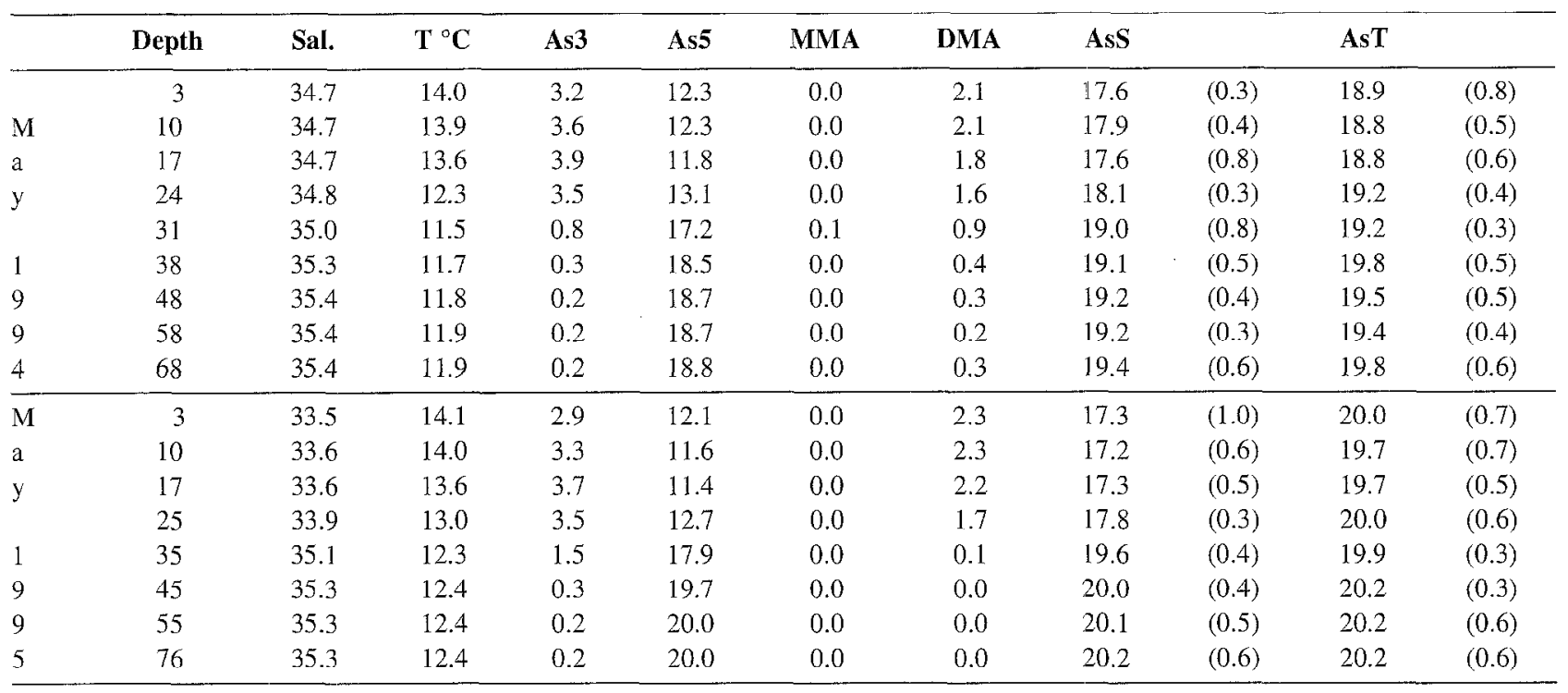

$20.9 \mathrm{nmol} \cdot \mathrm{L}^{-1}$ ). When arsenic input from the Gironde estuary is taken into account and a conservative dilution of 35.5 salinity is assumed, a theoretical profile of the distribution of dissolved total arsenic (AsTh) can be determined. This profile for the May 1995 cruise (figure 2) shows surface dissolved total arsenic concentrations greater than those in deep waters. The dissolved total arsenic (AsT) measured after complete mineralization of all forms of dissolved arsenic present in samples from the surface layer showed a slight but significant deficit (about $5 \%$ in 1995) in comparison with theoretical distribution.

The sum of arsenic chemical species (AsS), measurable by the generation of volatile hydrides, has often been considered equivalent to a determination of dissolved total arsenic. Howard and Comber [12] already showed that other organoarsenic compounds are not taken into account with this method since they did not produce volatile hydrides. Although this point was not confirmed by Cutter and Cutter [6] for oceanic waters, their study zone and season were less propitious to planktonic activity. In our study relating to surface waters with high biological activity, the difference between the two measurements (AsT-AsS) reached $13 \%$ in the euphotic layer. It is likely that arsenoriboside compounds resulting from photosynthesis [8] were present as well as arsenobetaine, whose existence up to high levels in food chains has been amply demonstrated [9]. The successive degradation products of these high-molecular-weight organoarsenic compounds are also likely to be present in the dissolved phase.

The distribution of reduced forms (As3 and DMA) was better correlated with the stock of chlorophyll $a$ than with primary production (figure 3). These two chemical species represent, respectively, 19 and $10 \%$ of the total arsenic in the surface layer. They are nearly inexistent below the pycnocline. It may also be noted that the As3 profile was maximal between 20 and $30 \mathrm{~m}$ of depth and slightly depressed at the surface (possibly because of more intense photochemical oxidation). MMA is sometimes found in the estuary or in coastal waters, in relation to certain plankton species or the degradation of other organoarsenic species $[25,26]$. Its presence often coincides with the summer season. In the spring, levels were not significant in our study either in 1994 or 1995.

\subsection{Particulate arsenic}

As noted earlier, in the Gironde estuary for salinities below 30, the proportion of particulate arsenic in the water column was thus nearly $50 \%$. For salinities above 35.5, the situation was quite different. At stations $A$ and $B$, less than $1 \%$ of particulate arsenic remained in the 


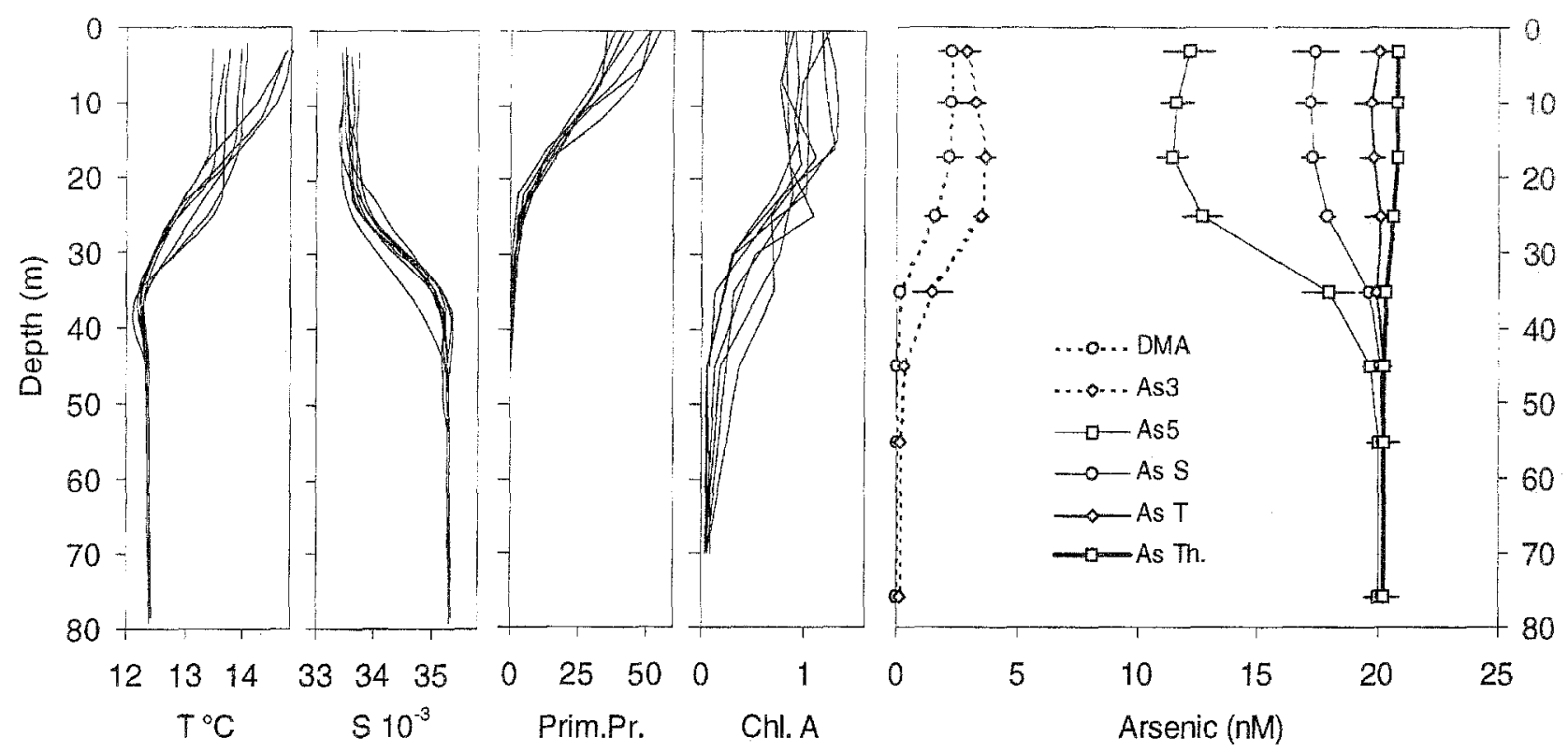

Figure 3. Daily vertical profiles at station B from 18 to 25 May 1995. For arsenic, the mean profiles and standard deviations are indicated for the same period. Prim.Pr. = primary productivity $\left(\mathrm{mg}(\mathrm{C}) \cdot \mathrm{m}^{-3} \cdot \mathrm{d}^{-1}\right)$, Chl.A $=$ Chlorophyll $a\left(\mathrm{mg} \cdot \mathrm{m}^{-3}\right)$.

Figure 3. Profils verticaux quotidiens à la station B du 18 au 25 mai 1995. Pour l'arsenic on a représenté les profils moyens et les écarts-types calculés sur la même période. Prim.Pr. = production primaire $\left(\mathrm{mg}(\mathrm{C}) \cdot \mathrm{m}^{-3} \cdot \mathrm{d}^{-1}\right), \mathrm{Chl} . \mathrm{A}=\mathrm{Chlorophylle} a\left(\mathrm{mg} \cdot \mathrm{m}^{-3}\right)$.

water column. The mean distributions of particulate arsenic, iron, aluminium and carbon in the water column for 1994 and 1995 are indicated in table II.

The difficulty of isolating phytoplankton from other particles accounts for the few comparative data available. Waslenchuck [31] based his assessment of arsenic on a concentration of $30 \mu \mathrm{g} \cdot \mathrm{g}^{-1}$, whereas the measurements of Benson and Summons [4] and Andreae [2] were, respectively, 9 and 2 to $3.5 \mu \mathrm{g} . \mathrm{g}^{-1}$. In our study, living or detrital phytoplankton constituted a large fraction (but not the totality) of the particles in the euphotic layer at stations A and $\mathrm{B}$. To evaluate the arsenic content in particles of planktonic origin, we thus used the $\mathrm{As} / \mathrm{Fe}$ and $\mathrm{As} / \mathrm{Al}$ regression lines (figure 4), whose extrapolation at the null abscissas enabled us to eliminate the interference of terrigenous particles. According to this procedure, phytoplankton would contain around $6 \mu \mathrm{g} \cdot \mathrm{g}^{-1}$ of arsenic, whereas all of the particles of the surface $25 \mathrm{~m}$ would contain between 5.1 and $9.0 \mu \mathrm{g} \cdot \mathrm{g}^{-1}$.

Conversely, the terrigenous particles at stations $\mathrm{A}$ and $\mathrm{B}$ were characterized by high iron and aluminium levels and arsenic concentrations ranging between 20 and $30 \mu \mathrm{g} \cdot \mathrm{g}^{-1}$. On this assumption, figure 4 simultaneously shows the
Table II. Mean results (and standard deviations) of suspended particulate matter (SPM) as a function of depth at station $\mathrm{A}$ in May 1994 and at station B in May 1995.

Tableau II. Résultats moyens et (écarts-types) des particules en suspension (MES) en fonction de la profondeur, à la station A en mai 1994 et à la station B en mai 1995.

\begin{tabular}{lccccccc}
\hline & $\begin{array}{c}\text { Depth } \\
\mathbf{m}\end{array}$ & $\begin{array}{c}\text { MES } \\
\left(\mathbf{m g} \mathbf{L}^{-1}\right)\end{array}$ & $\begin{array}{c}\text { As } \\
\boldsymbol{\mu g}^{-1} \mathbf{g}^{-1}\end{array}$ & & $\begin{array}{c}\text { Al } \\
\text { \% }\end{array}$ & $\begin{array}{c}\text { Fe } \\
\text { \% }\end{array}$ & $\begin{array}{c}\text { C } \\
\%\end{array}$ \\
\cline { 2 - 7 } $\mathrm{M}$ & 3 & 0.27 & 9.0 & $(1.4)$ & 0.43 & 0.14 & 51.6 \\
$\mathrm{a}$ & 10 & 0.39 & 8.1 & $(1.7)$ & 0.38 & 0.20 & 48.1 \\
$\mathrm{y}$ & 17 & 0.31 & 8.7 & $(1.8)$ & 0.47 & 0.22 & 42.0 \\
& 24 & 0.29 & 8.3 & $(1.8)$ & 0.67 & 0.28 & 50.8 \\
1 & 31 & 0.34 & 9.6 & $(1.7)$ & 1.02 & 0.54 & 41.4 \\
9 & 38 & 0.47 & 17.9 & $(0.9)$ & 3.17 & 1.88 & 26.1 \\
9 & 58 & 0.80 & 20.8 & $(1.0)$ & 4.65 & 2.74 & 15.5 \\
4 & 68 & 1.24 & 22.9 & $(1.0)$ & 5.32 & 2.96 & 8.0 \\
\hline $\mathrm{M}$ & 3 & 0.66 & 8.1 & $(2.2)$ & 0.13 & 0.03 & 32.2 \\
$\mathrm{a}$ & 10 & 0.60 & 6.8 & $(1.9)$ & 0.17 & 0.02 & 33.3 \\
$\mathrm{y}$ & 17 & 0.60 & 5.1 & $(1.2)$ & 0.18 & 0.08 & 30.8 \\
& 25 & 0.74 & 6.7 & $(1.9)$ & 0.39 & 0.09 & 22.9 \\
1 & 35 & 0.27 & 14.2 & $(2.1)$ & 1.99 & 1.01 & 32.0 \\
9 & 45 & 0.32 & 19.6 & $(2.2)$ & 3.09 & 1.92 & 21.5 \\
9 & 55 & 0.36 & 22.4 & $(3.2)$ & 3.67 & 2.16 & 19.0 \\
5 & 76 & 0.40 & 26.8 & $(3.8)$ & 4.36 & 2.62 & 16.5 \\
\hline
\end{tabular}



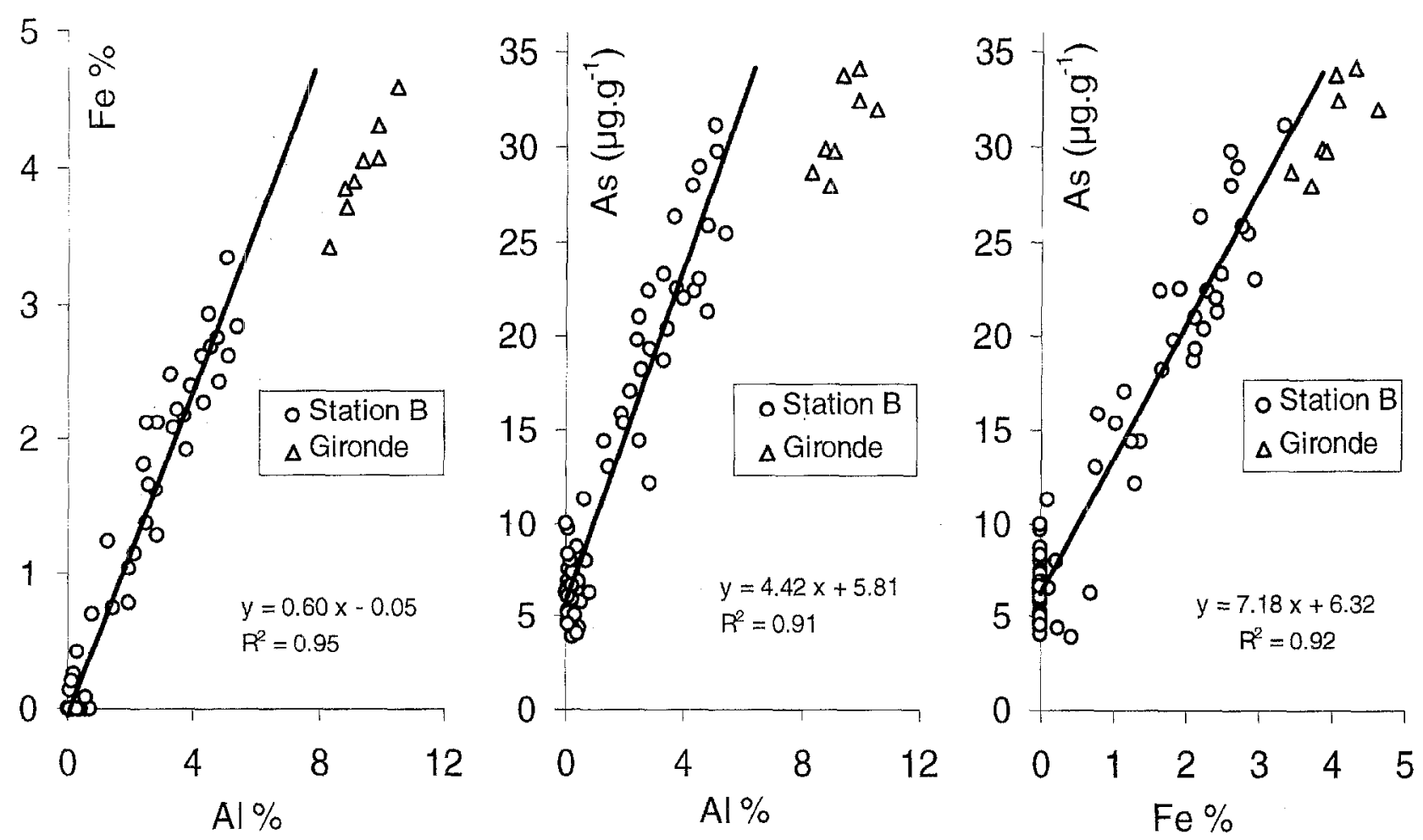

Figure 4. Characterization of suspended particulate matter (SPM) in May 1995. Fe and As concentrations in the particles are lower in the Gironde estuary than expected from the regression curve for station B.

Figure 4. Caractérisation des particules en suspension (MES) en mai 1995. Les concentrations en Fe et As dans l'estuaire de la (Gironde sont plus faibles que celles prévues par les droites de régression établies pour la station B.

$\mathrm{Fe} / \mathrm{Al}, \mathrm{As} / \mathrm{Al}$ and $\mathrm{As} / \mathrm{Fe}$ ratios in the Gironde estuary and at station $\mathrm{B}$, indicating the changes in these particles during their transport toward the ocean. If we consider that particulate aluminium is conservative, the divergence in the estuarine points relative to the regression lines indicates that the particles were enriched simultaneously in arsenic and iron after leaving the estuary. This enrichment might have been related to a partial redissolving of iron at the interface between water and reductive sediments and a subsequent coprecipitation of iron and arsenic in the deep water column.

It was noted earlier that the deficit in dissolved total arsenic in surface waters did not exceed $5 \%$. The role of phytoplankton in this deficit is quite minor, and the influence of terrigenous particles in this zone subjected to river inputs remains dominant. We are in the presence of an ecosystem in which recycling is very important $[10$, 15]. Planktonic composition was dominated by cells smaller than $3 \mu \mathrm{m}$, which account for more than $50 \%$ of chlorophyll production. This phytoplankton is consumed by equally small zooplankton species, resulting in a slow rate of decrease in detrital particles and feces and their nearly total degradation in surface waters. This process was confirmed by examination of particles collected in the trap, which contained very little carbon of phytoplanktonic origin.

\subsection{Comparison of arsenates and phosphates: vertical fluxes}

The arsenate profile has often been compared with that of phosphates $[19,30]$. More precisely, the comparison concerns $\mathrm{AsO}_{4}{ }^{3-}$ (As5) and $\mathrm{PO}_{4}{ }^{3-}$ (reactive phosphorus). The results obtained here confirm an apparent behavioural similarity for these two elements. In fact, there was a nearly total exhaustion of phosphorus in the surface layer, correlated with an As5 deficit of around $50 \%$. However, major differences can be noted in the seasonal divergence and cycle amplitude of these two elements. From the beginning of our cruise, winter and post-winter phyto- 
planktonic production had already exhausted the phosphorus stock available. According to Herbland et al. [10], phosphorus in this zone is considered as a limiting factor on primary production, and residual productivity (which remains high) is only supplied by the recycling of dissolved or particulate organic phosphorus. For arsenic, on the contrary, it seemed that an equilibrium already existed, despite the fact that the temperature favouring arsenic assimilation had been just recently attained. Thus. we noted no significant differences in As5 concentrations from 3 to 25 May 1995. The high levels of As3, for which photochemical oxidation is rapid, and the DMA concentrations indicate that the metabolization of arsenic by phytoplankton continued actively but that recycling by degradation of organoarsenic species and by As3 oxidation was adequate to supply the system without ever exhausting the available As5.

For the deep waters of the North Atlantic, Middelburg et al. [19] determined that arsenic and phosphorous deficits were linearly correlated and that the $\Delta \mathrm{As} / \Delta \mathrm{P}$ molar ratio was $2.5 \times 10^{-3}$. Statham et al. [30] noted that this ratio may depend on the age of the water masses. In our study, the $\Delta \mathrm{As} / \Delta \mathrm{P}$ ratio was $2.6 \times 10^{-2}$ and not significant, being influenced by the phase difference in the seasonal cycles of arsenic and phosphorus.

To estimate the vertical arsenic flux, it is essential to take into account all dissolved and particulate chemical species. Millward et al. [20] studied the uptake of dissolved inorganic arsenic by the diatom Skeletonema costatum. They showed an uptake rate of $0.55 \mathrm{nmol} \cdot \mathrm{L}^{-1} \cdot \mathrm{d}^{-1}$. In the southern North Sea, Millward et al. [21] has shown that the diatom assimilation rate was $0.57 \mathrm{nmol} \cdot \mathrm{L}^{-1} \cdot \mathrm{d}^{-1}$ corresponding to a phytoplankton removal of dissolved inorganic arsenic species of 9 to $17 \mathrm{nmol} \cdot \mathrm{L}^{-1}$. Millward et al. $[22,23]$ estimated an annual biologic uptake of $215000 \mathrm{~kg}$ in the Humber Plume and $90000 \mathrm{~kg}$ in the Thames Plume. The results of our study contrast with the conclusions of previous authors concerning the role of phytoplankton in the arsenic cycle in coastal areas. The deficit of dissolved inorganic arsenic by phytoplankton exists but is lower than $4 \mathrm{nmol} \cdot \mathrm{L}^{-1}$ in May 1994 and $5 \mathrm{nmol} \cdot \mathrm{L}^{-1}$ in May 1995. Furthermorc, the uptake of dissolved inorganic arsenic by phytoplankton does not mean that arsenic is removed from the water column; we have found that most of this uptake is recycled with simultaneous increase of the concentration for organoarsenic species, including those not directly measurable by hydride generation (figure 3, table i). When we take into account the total arsenic (AsT) as measured after mineralization, the deficit compared to theoretical values is less than $2 \mathrm{nmol} \cdot \mathrm{L}^{-1}$; furthermore, part of this deficit should be attributed to removal by iron hydroxydes in the Gironde Plume. These observations are in agreement with Herbland et al. [10] and Iahorde et al. [15], who showed during the same cruises that residual phosphorus level was not significant and that primary production due to small phytoplankton species was only activated by recycling of nutrients. The total recycling of phytoplankton in the euphotic layer explains the low arsenic vertical flux attributed to the biological activity at the stations $\mathrm{A}$ and $\mathrm{B}$.

\section{CONCLUSIONS}

On the basis of an estimation of arsenic flows from the Gironde estuary, this study in a coastal zone during an active period of primary production confirms a certain analogy between arsenates and phosphates as well as the formation of reduced species such as As3 and DMA. Moreover, it demonstrates the importance of organoarsenic species not directly accessible to the formation of volatile hydrides. These species account for up to $13 \%$ of dissolved arsenic in the euphotic layer. Once they are taken into account, the deficit in dissolved total arsenic in the surface layer represents only $5 \%$. The level of arsenic in phytoplankton was estimated at $6 \mu \mathrm{g} \cdot \mathrm{g}^{-1}$ compared to 20 to $30 \mu \mathrm{g} \cdot \mathrm{g}^{-1}$ in iron- and aluminium-rich terrigenous particles. Although this finding does not invalidate the importance of phytoplankton in dissolved arsenic speciation, its involvement in vertical transfers does not seem to have been predominant in the study zone. The removal of dissolved arsenic from the water column by iron hydroxydes in the Gironde Plume is probably more important and should be investigated in a further study.

\section{Acknowledgments}

The authors sincerely thank all the teams participating in the PNOCAT and BIOMET cruises for their material and intellectual contribution to this study. They are also grateful to the authorities of the National Coastal Oceanography Program for funding. 
[1] Andreae M.O., Distribution and speciation of arsenic in natural waters and some marine algae, Deep-Sea Res. 25 (1978) 391-402.

[2] Andreae M.O., Organoarsenic compounds in the environment. in: Organometallic Compounds in the Environment, Ed. P.J. Craig, Leicester U.K., 1986, p. 198-228.

[3] Andreae M.O., Klump D.K., Arsenic uptake and metabolism by marine phytoplankton, Environ. Sci. Technol. 13 (1979) $738-741$.

[4] Benson A.A., Summons R.E., Arsenic accumulation in Great Barrier Reef invertebrates, Science 211 (1981) 482-483.

[5] Boyle E., Collier R., Dengler A.T., Edmond J.M., Ng A.C., Stallard R.F., On the chemical mass balance in estuaries, Geochem. Cosmochim. Acta 38 (1974) 1719-1728.

[6] Cutter G.A., Cutter L.A., Behavior of dissolved antimony, arsenic and selenium in the Atlantic Ocean, Mar. Chem. 49 (1995) 295-306.

[7] Ebdon L., Wilkinson J.R., Jackson K.W., A simple and sensitive continuous hydride generation system for the determination of arsenic and selenium by atomic absorption spectrometry and atomic fluorescence, Anal. Chim. Acta 136 (1982) 191-199.

[8] Francesconi K.A., Edmonds J.S., Arsenic in the sea, Oceanogr. Mar. Biol. Ann. Rev. 31 (1993) 111-151.

[9] Hanaoka K., Yamamoto H., Kawashima K., Tagawa S., Kaise $T$., Ubiquity of arsenobetaine in marine animals and degradation of arsenobetainc by sedimcntary micro-organisms, Appl. Organomet. Chem. 2 (1988) 371-376.

[10] Herbland A., Delmas D., Laborde P., Artigas L.F., Sautour B., Does phosphorus limit the phytoplankton spring bloom in the Gironde Plume waters on Bay of Biscay continental shelf? Oceanol. Acta (1998) (this issue).

[11] Howard A.G., Arbab-Zavar M.H., Apte S.C., The behaviour of arsenic in estuary of the River Beaulieu, Estuar. Coast. Shelf S. 19 (1984) 493-504.

[12] Iloward A.G., Comber S.D.W., The discovery of hidden arsenic species in coastal waters, Appl. Orgmet. Chem. 3 (1989) 509-514.

[13] Howard A.G., Comber S.D.W., Kifle D., Antai E.E., Purdie D.A., Arsenic speciation and seasonal changes in nutrient availability and micro-plankton abundance in Southampton Water, U.K., Estuar. Coast. Shelf S. 40 (1995) 435-450.

[14] Jouanneau J.M., Matières en suspension et oligoéléments métalliques dans le système estuarien girondin: comportement et flux, Thèse de Doctorat es-Sciences, Université de Bordeaux I, (1982) 306 p.

[15] Laborde P., Artigas L.F., Delmas D., Herbland A., Sautour B., Biogenic particles fluxes during spring at the bottom of the euphotic zone in the Gironde Plume (French continental shelf, Bay of Biscay), Oceanol Acta submitted.
[16] Lazure P., Jégou A.M., 3-D Modelling of seasonal evolution of Loire and Gironde Plume on Biscaye Bay continental shelf, Oceanol. Acta 21 (2) (1998) 161-173.

[17] Michel P., Averty B., Noel I., Sanjuan J., Evaluation of dissolved and particulate arsenic flux in the Strait of Dover ("FluxManche' program), Oceanol. Acta 16 (1993) 585-591.

[18] Michel P., Averty B., Colandini V., Improvement in arsenic speciation using hydride generation and atomic absorption spectrometry, Miktochim. Acta 109 (1993) 35-38.

[19] Middelburg J.J., Van Der Sloot H.A., Van Der Weijden C.H., Wiijkstra J., Arsenic, antimony and vanadium in the North Atlantic Ocean, Geochem. Cosmochim. Acta. 52 (1988) 2871-2878.

[20] Millward G.E., Ebdon L., Walton A.P., Seasonality in estuarine sources of methylated arsenic, Appl. Organomet. Chem. 7 (1993) 499-511.

[21] Millward G.E., Kitts H.J., Comber S.D.W., Ebdon L., Howard A.G., Methylated arsenic in the Southern North Sea, Estuar. Coast. Shelf S. 43 (1996) 1-18.

[22] Millward G.E., Kitts H.J., Ebdon L., Allen J.I., Morris A.W., Arsenic species in the Humber Plume, U.K., Cont. Shelf Res. 17 (1997) 435-454.

[23] Millward G.E., Kitts H.J., Ebdon L., Allen J.I., Morris A.W., Arsenic in the Thames Plume, U.K., Mar. Environ. Res. 44 (1997) 51-67.

[24] Murphy J., Riley J.P., A modified single solution method for the determination of phosphate in natural waters, Anal. Chim. Acta 10 (1962) 31-36.

[25] Riedel F.R., The annual cycle of arsenic in a temperate estuary, Estuaries 16 (1993) 533-540.

[26] Sanders J.G., Role of marine phytoplankton in determining the chemical speciation and the biogeochemical cycling of arsenic, Can. J. Fish. Aquat. Sci. 40 (suppl. 2) (1983) 192-196.

[27] Sanders J.G., Arsenic geochemistry in Chesapeake Bay: dependence upon anthropogenic inputs and phytoplankton species composition, Mar. Chem. 17 (1985) 329-340.

[28] Sanders J.G., Alteration of arsenic transport and reactivity in coastal marine systems after biological transformation, Rapp. P.-v. Réun. Cons. int. Explor. Mer. 186 (1986) 185-192.

[29] Seyler P., Martin J.M., Distribution of arsenite and total dissolved arsenic in major French estuaries: dependence on biogeochemical processes and anthropogenic inputs, Mar. Chem. 29 (1990) 277-294.

[30] Statham P.J., Burton J.D., Maher W.A., Dissolved arsenic in waters of the Cape Basin, Deep-Sea Res. 34 (1987) 1353-1359.

[31] Waslenchuk D.G., The budget and geochemistry of arsenic in a continental shelf environment, Mar. Chem. 7 (1978) 39-52. 